\title{
The Idea of Perfect Man
}

\section{Mohammad Reza Najjarian}

Associate Professor, Department of Persian Language and Literature, Yazd University, Yazd, Iran

Email: reza_najjarian@yazd.ac.ir

How to cite this paper: Najjarian, M. R. (2016). The Idea of Perfect Man. Open Journal of Philosophy, 6, 319-334.

http://dx.doi.org/10.4236/ojpp.2016.64032

Received: January 5, 2016

Accepted: September 26, 2016

Published: October 13, 2016

Copyright (@) 2016 by author and Scientific Research Publishing Inc. This work is licensed under the Creative Commons Attribution International License (CC BY 4.0).

http://creativecommons.org/licenses/by/4.0/ (c) (i) Open Access

\begin{abstract}
Different religions have one belief in common in that man is not self-existent. It means that his life is basically dependent on an independent central power. This concept was suggested by early religions in the form of the belief that nature has powers, but more advanced religions have a belief in a metaphysical being, who is the creator of the world. Besides human desire for perfection is a common subject that connects different religions to each other although there exist various interpretations about perfection and perfect man. The basis of the western new thought is humanism, in which human is a self-centered one and is not dependent on any greater force; however, in the eastern thought, man and the world are under God's centrality, moving toward a spiritual goal and a superior world. This article aims at the position of the perfect man, as a creature on the earth, in the worlds of Darwinism, Marxism, Nietzcheism, Freudism, Buddhism, Confucianism, Taoism, Mazdaism, Manichaeis, Judaism, Christianity, and Islam. It is concluded that among all eastern religions, Islam is the only multi-dimensional one and considers both materialistic and spiritual dimensions of man.
\end{abstract}

\section{Keywords}

Perfect Man, Darwinism, Buddhism, Taoism, Mazdaism, Judaism, Christianity and Islam

\section{Introduction}

Man is the most mysterious species of the universe who, despite all the continuous efforts of thinkers, has not been understood yet. The real understanding of man is tantamount to the discovery of the secret of creation. The "Big Bang" theory and its importance are to be discussed here in connection with the recognition of man's entity.

Three basic subjects that have been discussed in the western thought since the ancient times are man, universe and God. Of course, the relative importance of each has been different at different points of time. It was only after Renaissance that man got to 
be the main focus of attention instead of theology and metaphysics and, in the form of "first philosophy", it became the basic foundation for other philosophical branches. During Renaissance, i.e. 15th and 16th centuries, a great revolution happened in people's thoughts, and the center of western beliefs changed from the heaven to the earth. In 19th century, since Georges Lemaitre first noted that an expanding universe might be traced back in time to an originating single point, scientists have built on his idea of cosmic expansion and the west has accepted the Big Bang theory as the prevailing cosmological model for the universe. In this century, which is the era of romanticism, under the influence of thinkers like Darwin, Marx, Nietzche and Freud, the view towards man and the world were totally changed in the West, and the meaning of everything was hidden in this world. In contrast, the Eastern man, under the influence of religions that appeared in the East, has always been searching for a valuable truth beyond materialism and a transcendental world.

In this article, our main goal is analyzing the characteristics of perfect man in western philosophies and eastern religions as well as four nationally-recognized western thinkers, Darwin, Marx, Nietzsche and Freud that their ideas play an important role in 19th century. We are also trying to check out the major religious ideas in India, China, Iran and the three Abrahamic religions about the ideal man, finally we compare these views to understand the Differences between western and eastern ideas and distinguish the best idea bout perfect man.

\section{Schools of Thought}

\subsection{Darwinism}

Charles Robert Darwin (1882-1809) was a British biologist and the founder of the theory of "Evolution". Before his theory, biological theories were based on the "Fixism" theory which was in harmony with theological and philosophical theories of that time. Until the 18th century, the dominant idea was that "God has created certain frames and forms for different kinds of creatures, and every creature was originally created in the shape that we see it today (Foroughi, 1961).

Darwin published "Origin of Species" at the age of fifty and caused a great revolution in science and philosophical schools. His theory is one of the most important and effective ones in anthropology. According to it, creatures change little by little which is caused by environmental effects, struggle for survival, and choice of nature which is due to the nonstop struggle among creatures to stay alive and to keep their corresponding communities in balance. In this struggle, those who are more qualified and stronger and can adapt to nature better will win and survive, but those who cannot will disappear. The characteristics of the superior group, according to the law of succession, transfer to the next generation. Then, in each generation, it will reach a higher degree of perfection and, after several generations, there will be a new species of creatures that are different from their ancestors. The creatures, thus, continue to develop steadily. The summary of Darwin's theory is that creatures were not created in the same form as they are now; rather, through natural choices and the effect of environment, they have 
gradually developed into their present form.

In the beginning, Darwin did not mention anything about man, but, after ten years in the book of "The Descent of Man", he described man as a developed kind of imperfect animal. According to his theory, "the difference between human and the other animals is not in species but in their dignity; it is actually in their strengths and weaknesses. In contrast, based on Islamic scholars' interpretation, there is no substantial difference between human and other species. Human brain and his intelligence are just more advanced than monkeys, and the primitive people belong to the intermediate link between humans and developed monkeys" (Pirmoradi, 1995).

In fact, denying all the differences between human and animals, Darwin said, "human has no special physical characteristics, and his desires, though developed very much, are not his absolute features; rather, they are similar to superior animals' instincts because animals too usually dream and sometimes feel horrors which are products of their imaginations. Human affection exists in other animals too. There is perfect maternal affection in female animals, but it does not remain long enough like in men. Another feature is friendship which is not found just in men. Motherless baby monkeys are always under elder monkeys' kindness and support. We can see jealousy, hatred, grudge and heedlessness in animals too. Animals are even sensitive to beauty, color, songs and music. Human is not the only moral creature in the world; animals make each other aware of dangers and help each other find food too" (Behzad, 1959).

Darwin put human in the family tree of monkeys and stated that "Lemure" could be the ancestors of today's monkeys. So, casting a natural look at humans, Darwin called them developed animals and believed that humans can be more advanced in near future.

\subsection{Marxism}

Karl Heinrich Marx (1883-1818) was a German thinker, revolutionist, philosopher, socialist and economist. Some people do not know him as a philosopher but consider his school as an economic, political and social frame of mind. Also, some believe that his philosophical thoughts are only a combination of the ideas of Hegel (1831-1770) and Feuerbach (1872-1804). However, as the truth is, Marx school is primarily a philosophy because all of his political efforts and oppositions with capitalism, private ownership and division of tasks were on the basis of his opinion that human freedom depends on his freedom in the society. Marx believed that human social dimension is more important than his psychological dimension and that he is a member of the society and the product of history, so he cannot improve and have freedom without basic changes in social communities and economies.

Marx believed that "Work" is the essence of man, his means to grow and improve his talents, and the basis of his existence. As it has been stated, "man shows himself in his work, through which his spiritual, individual and physical powers are projected. It is the real process of activity in which he makes himself perfect and attains the entirety of his self" (Piyetr, 1973). 
In Marx's point of view, an imperfect man is a stranger to himself because he is forced to work strangely not freely to make a living. Free working will exist in a free society without any limitation but with partnership. So, there must be a revolution in which man as a person can cause changes and change himself. So far, all revolutions have been imperfect movements, but an obvious one is the "communist revolution" in which man will change totally and a communist society or Marx's earthly paradise will be created. In this society, religion and gnosticism will disappear. Marx believed that government and religion can cause human alienation.

The core of the above-mentioned points is that "Marx was interested in the social aspects of man and not his individual aspects. He views perfect man as a man without a special status or class in the society. He believed that, if a person belongs to a class of society especially superior classes, he or she will remain imperfect. Also, in a classbased society, it is basically impossible to find any perfect man. In Marx's school, perfect man is a person who is always equal to others and lives in the same situation as others. So, the basis of getting perfect in this school is being "We" not "I", and the basis of being "We" is deleting specialties and replacing individuality with community" (Motahari, 1978).

\subsection{Nietzcheism}

Friedrich Wilhelm Nietzche (1900-1844) was a German philosopher and poet. His central idea is "will power". He once said, "This is my happiness that after these thousands years of disturbance and confusion, I have found a way that leads me to a yes and a no. I say "no" to what makes me weak, and I say yes to what makes me strong and powerful" (Nietzche, 2011; Nietzche, 1956).

Because "being strong" is not related to "morality", Nietzche denied all moral virtues such as justice, sympathy, kindness and love for fellow creatures, and he believed that "our first duty is to care about our own existence. Ethics which teaches us to think about others before thinking about ourselves is going to the opposite way" (Babak, 1957).

Nietzche admitted man's binary nature, but he believed that his physical aspect is more important than his soul. As he put it, “All my existence is my body and that's all. My soul is a word for a part of body" (Nietzche, 2011).

Nietzche believed that God is dead and "the superman" has replaced him. In his point of view, man is a bridge between the animal and the super man. Being human is not the goal, but, in fact, he should destroy his current situation to get to the point of perfection. This means getting closer to being superman or to his real self.

Nietzche's super man is not a metaphysical one who is waiting for another world, but he enjoys this world and loves life. It has been stated that "actually this world that people have to live in and to relate to is called unreliable; the true world is the most dangerous killer of life" (Saneyi Darre Bidi, 2006).

Nietzche thought about an individual not the public because he believed that man's society will never be corrected and the sole aim is to make strong and powerful men. 
He divided people into two groups: the superiors who are knights, champions, heroes and adventures and the inferiors who are simple and escape dangers and prefer to be under control of the former group. He said, "Common people have their own place, but they do not have to take control of the government. An ordinary person is the one who is happy in his right place. Men are perfect when they are economical, in order, modest and pious" (Durant, 1971). He denied equality and democracy and believed that in democracy the super man cannot appear and governorship is the natural right of the superior not the common people.

Therefore, the perfect man in Nietzche's opinion is a strong man who reaches the freedom zone and denies all old values and moral limitations. He loves earthly life and does not care about spiritual and imaginative worlds. Everything comes from his own will, and his main goal is achieving strength and power. To gain power, he does not rely on knowledge and wisdom but gets benefits of his instinct and creativity. Also, he enjoys living without believing in any moral scruples.

\subsection{Freudism}

Sigmund Freud (1939-1856) was an Austrian psychologist and the father of "psychoanalysis". His basic opinion about man divides man's mind into "consciousness" and "unconsciousness". He believed that unconsciousness comes from consciousness and is a part of it and, basically, it is a source of everything that we repress such as thoughts, feelings, memories, and desires which are against moralities. He believed that the only reason for disturbances and mental disorders is repressing our desires especially sexual ones which he evaluated as the strongest instinct in man. In Freud's opinion, man's repressed desires will enter his dreams; in fact, dreams are something that symbolically shows these repressed desires when we fall asleep and there is a decline in awareness.

Freud divided human mind into three parts including "Id", "ego" and "super ego". Id is the oldest zone of the mind and the source of all desires and instincts which are in human from birth. Its aim is to increase joys and decrease depressions, and it does not care about laws, social obstacles, and moral limitations. When an individual participates in the society, some parts of his or her id are changed to ego, which is an intermediate phase between id and the outside world. Ego is the factor that controls the mind rationally; it decides to satisfy id's needs or repress them, and its aim, like id's, is to enjoy but, by considering the reality, it delays enjoyment to an appropriate time. So, we can relate ego to awareness. Also, the individual's growth and training make a third power in his or her mind, which is called super ego. This is the result of parents' and teachers' trainings with a system of encouragement or punishment for right or wrong actions. Super ego is the content of religions and social customs.

It can, thus, be said that, in man's mental system, id is related to desires and depends on "the pleasure principle", ego is related to wisdom and depends on "the reality principle", and super ego is related to conscience and depends on the "moral principle". Id and super ego work against each other; the first one is in search for satisfying its desires without limitations, but the aim of the second one is to control and repress them. Ego is 
there to make a balance in the mind and is under pressure between these two powers and the outside world. If ego gets weak, man will suffer from disturbance. So, the goal of psychoanalysis is to help and strengthen the ego.

Freud believes that "if super ego did not exist, id would get to its aim which is pleasure, and man would be healthy and normal. But this hypothesis is impossible because of civilization, training and values. Although all men suffer from disorders, they can get relatively healthy by strengthening the ego, or the rational element, which shows normality and health in Freud's theory" (Aboutorabi, 2001).

Freud attacks religions and says that religion limits logic and wisdom and is the cause of repressing desires. He believes that there is no benefit in being pious. According to him, "This is right that religion controls our social desires, but it does not do anything worthwhile; it does not make us happy; it does not let us care about our sexual desires and, worse of all, does not help individual's growth. Religion is a kind of resenting temptation and, therefore, being religious is related to the imaginative and childish part of living" (Palmer, 2009). In fact Freud believed that religion is on illusion and the repetition of childhood experiences; just as a child knows how to fight with his insecurity by relying on his father, praising him, and being afraid of him, so man fights with dangerous forces around him by relying on God and praising him .

Therefore, Freudian belief is against religion and metaphysics. Instead, it advocates knowledge and rationalism. In general, Freud believed that man is naturally seeking pleasure not for perfection because he can be perfected when he avoids metaphysics, acts upon his nature and desires, and responds positively to his inner instincts.

\subsection{Hinduism}

Hinduism is considered as the main religion in India practiced since the 8th century B.C. It is based on "Vedas" (i.e. the oldest collection of Hindu holy writings from 1500 to $500 \mathrm{BC}$ ). Its basic principle is to believe in "unity of beings", "unity of gods", "unity of religions", "divinity of souls", "denial of dualists", "reincarnation", and "necessity of Mortification."

Hindus believe in one indefinite source which they call "Brahma". The goal of a Hindu is to be the one with Brahma. In Hinduism, Brahma is actually our own soul. There are millions of gods because we are all god.

Perfect man in Hinduism is somebody who "as he sees things, he says to himself 'It's you!' (Tat twamasi)". This phrase shows the unity of things with others and also with Brahma, suggesting an experience of witnessing which depends on purification of the soul and being free from reincarnation. This experience is called connection or "Turia" (Zarrinkoob, 1990).

Hindus believe that man has been created for perfection and he should get it in this life. If he does not succeed, he will be born again and again. In every life, man's future and class of society which he is born in will be determined according to his deeds and thoughts in his previous lives. So, in this philosophy, man is not born innocent, but his birth is based upon the results of his deeds in previous lives. This law of action and 
reaction is called "Karma". "Perfection needs removing this Karma because it causes rebirth. Man has to discover "Atman" which is his real self to reveal out of dark layers of Karma" (Shaker, 2011).

Perfection in Hinduism, thus, means being free from rebirth and continuous lives, and this freedom is possible by killing " $\mathrm{I}$ " and knowing "Atman" through mortification and purification. Perfect man in Hinduism focuses all his attention on the absolute truth by putting this world and his physical interests aside. He denies his individuality and feels in unity with universe, so, after his death, he will go out of the circle of life and death to the other world which is called "Nirvana".

\subsection{Buddhism}

Buddhism was founded by "Siddhartha Gautama", also known as "Buddha" (meaning awakened) who was an Indian prince in the 6th century B.C. Buddhism, which is one of the branches of Hinduism, has been influenced by some of the main principles of Hinduism such as "Karma law", "reincarnation", "the subject of freedom" and "joining Nirvana", but it has a different method of how to get out of the life and death circle. Buddhism is also a godless religion contrary to Hinduism which is the religion of many gods.

The basic belief is that, in man's life, there is more suffering than happiness to the extent that man would rather not have been born, and that his duty is to recognize this suffering and set himself free.

Buddha believed everything in the world is changing, whatever comes to existence is bound to be destroyed, suffering is the foundation of the world, and, in fact, changing and suffering have the same meaning. Perfect man in Buddhism is the one who knows this truth and knows what suffering is, how it can be made and how it can be taken away. In Buddha's opinion, "man is the captive of ignorance, and this ignorance means not knowing the realities of Buddhism which is related to the truth of worldly suffering. A perfect man is the one who can be free from four ignorances and get to four truths. The four ignorances include not knowing the suffering, not knowing the source of it, not knowing how to get rid of it, and not knowing what can put the suffering out. These are versus four Buddhist truths. Firstly, whatever comes to existence has to suffer. Secondly, the source of suffering is birth because every birth is followed by a death. Thirdly, having freedom and salvation can happen by stopping the circle of life and death. Finally, we can attain this goal by eight principles including right belief, right thought, right word, right deed, right life, right effort, right decision and right care" (Shaygan, 1967).

Therefore, the cause of suffering in Buddhism is man's birth, and its cause is man's strong desire for it. To be free from the sufferings and to purge life from desires, one has to avoid his materialistic desires. A perfect man in Buddhism is the one who gets himself free from the instability of the world, releases himself from the life and death circle, and gets to "Nirvana", which is the happiness and light. Nirvana is the main aim and principle in Buddhism and means reaching absolute silence and stability without any suffering. 


\subsection{Confucianism}

Confucianism is a social and logical school which is based on ancient Chinese customs and moralities. It was founded by Confucius who was a Chinese thinker and politician in the 6th century B.C. His real name was "Chiu Kung", and his students called him Kung-Fu-Tze which meant great professor, and "Confucius" is the Latin equivalent of this word. Before Confucius, poverty, corruption and superstitions were at their extreme. He believed that the only way to set people free from corruption and destruction is to return to the culture of the ancient China. In fact, Confucius was a moral teacher and a social reformer whose school is not related to metaphysics.

The ideal man in Confucianism is completely moral, and his basic religious belief is that, "if a man implements moral rules correctly, he acts in harmony with the heaven's will" (Nas, 1991).

Confucius does not have any guide for man except wisdom, and he even does not care about the moralities which are not the bases of wisdom. So, he does not like to react to evil by goodness like "Laozi" and "Jesus" did, but he believes that we should act against evil by justice.

He also believes that, for social reforms, we should first reform individuals. He says, "Society orders need government orders, and government orders need family orders, and family orders need super moralities in individuals" (Zarrinkoob, 1990).

Therefore, Confucius's instructions are not religious and theological but moral orders. His perfect man is "a boy who keeps his parents' affections in his heart, a father who behaves his children kindly and fairly, a soldier who is faithful to his general, a husband who is intimate to his wife, and a friend who is polite and pure with his friend" (Nas, 1991: p. 384).

Confucius says that "a perfect man is highly value-minded and does not follow any one. He is modest in words because he knows that people may make distortions easily in their speech. He is a man of action not words. A perfect man searches for everything in himself while an inferior man searches what he wants in others. A perfect man is worried that he might not find the truth, but he is not afraid of poverty. He is sad about not having skills and abilities but not about being unknown among people" (Durant, 1971).

In summary, by putting metaphysical discussions aside, Confucius tried to train an ordinary person in a usual family in order to reform the society. This is because he believed that the perfection of a society depends on the perfection of individuals. $\mathrm{He}$ founded his instructions by following wisdom, knowledge and moralities and introduced "perfect man" as a person who is harmonious, brave, seeking goodness in others, man of action, modest and balanced in words and deeds.

\subsection{Taoism}

Taoism, or the Chinese gnosticism school, is attributed to a Chinese thinker whose name was "Laozi" (i.e. old professor). His life has remained in ambiguities and legends. Some of his instructions that have been written in the book "Dao de Jing" (book of 
method and virtue) are not known as the product of one person's thoughts but have been in use since many years ago. This ideology started in the 6th century B.C. Unlike Confucianism, this school is based on the harmony with rules of nature system and is anti-wisdom, anti-social, and individualist.

Taoist instructions try to adjust man's life with natural rules. It also patterns all the existence upon "Tao", which means "method" in Chinese and, idiomatically, is a fixed law on the basis of which the world moves. Harmony with nature is the result of the movement based on Tao. Tao can be explained as an absolute principle and an unknown source which everything is deduced from. In brief, it is the basis of universe. Laozi says: "There existed something ambiguous before the creation of the heaven and the earth; something uneasy, unchangeable and abstract which works indefatigably. It can be the mother of everything, I don't know its name although the name 'Tao' is devised for it" (Ashoori \& Chinese, 1963).

The difference between Tao and the usual imagination of God is that God has created the world by making but Tao has created it by not making. Tao does not know how he has created this world because it acts automatically. This "automatic action" is the foundation of Tao's instructions. Being automatic is the characteristic of every living being like sunshine and moonlight, water flow and plant growth. Due to their harmony with Tao, the heaven and the earth have come to their perfect order and equilibrium. Man, who is a part of nature, has to follow his natural path for perfection and salvation. It means he should be in harmony with nature, avoid any artificiality and compulsion and have spontaneity so as to gain perfection in his life. These actions are interpreted as harmony and accompaniment with Tao. Tao is not done by any special actions but by not acting and not trying to change the normal system of nature.

Accordingly, a perfect man in Taoism leaves everything to its natural way, and this manner is called "Wu Wei", or inactivity and submission. "Laozi's ideal life is based on the $\mathrm{Wu}$ Wei theory. He taught not only avoidance of actions or passivity but also joining mortality. His natural example for living is water behavior; in the world, there is nothing more flexible and softer than water though it prevails the hardest things" (Ibid, 16).

In Tao's school, a perfect man is truthful to nature, and nature leads him to happiness. He is free from desires and does not search for knowledge. He goes in for absolute submission and satisfaction, stays away from thinking and wisdom, and gets along with nature. He is simple, submissive and humble but not weak and mean because that submission and simplicity give him a power which others are deprived of. His characteristics are trust, patience, kindness and seclusion. He leaves everything to its natural manner by not seeing, not hearing and not acting because he is aware of nothing and moves forward with nature.

\subsection{Mazdaism}

Mazdaism, or the religion of God worshiping, is also called "Zoroastrianism" after its leader Zoroaster (i.e. who has a yellow camel). It advanced in Iran after several years of 
Iranian Aryans separation from Indians. The exact birth time and place of Zoroaster is not known, but it is guessed to have been between 6000 and 600 years before Christ. The most likely time of his life is said to be at the end of the 7th century and the beginning of the 6th century BC, and his birth place might have been somewhere such as Rey, Azerbaijan, Khwarazm or Sistan. What is clear is that a person by the name Zoroaster who was from the clerical background of the eastern part of Iran and was known as a poet of religious hymns rebelled against Arian religion and gods, rites, old customs, oppression and injustice. Owing to his specific social situation, he could found a new religion as a response to Iranians' suffering and needs and reformed the economic and social situations. He resisted living in tents and invited people to build houses and dwell there because he believed civilization was not in conformity with tribal life. He was against eating too much meat and killing cows because, by doing so, poor people would lose their properties. He also denied witchery, decreased religious ceremonies, and made a new religion based on agriculture. Zoroastrianism is a religion full of efforts and joys of life but does not accept any seclusion. According to Zoroaster's instructions, man has to work, and the most suited job is agriculture.

Before Zoroaster's time, Iranians worshiped many gods, but he unified all Aryan gods, which were called "Daeva", and called it "Ormazd". He taught that there was only one God worth worshiping; a god with the power of light, truth and goodness. The quality of Zoroaster's instructions is based on duality, but there is no evil against Ormazd. "Angra Mainyeu", or the evil wisdom, which changed into "Ahriman" to whom all the evils of the world are attributed, is not against Ormazd; rather, it is against "Spanta Maineyu", or the holy wisdom that created all good deeds. "Thus, light, beauty, fire, cow, and all useful creatures as well as all goodness have come to existence from a good essence. In contrast, darkness, ugliness, harmful creatures, non-Aryan people, sickness, pains, beasts, death and all evils are born out of Ahriman or Satan. Since Zoroastrianism believes in the two contrastive concepts of goodness and evil, it is considered as a dual religion" (Mashkoor, 1980).

In this religion, the world is the arena of a continuous war between two forces, good and evil. Every one's duty is to be on the good side, and this can be possible by having good thoughts, good words and good deeds. These three principles form the basis of Zoroaster's religion. They emphasize truth and honesty and discourage telling lies and dishonesty.

On this basis, man has to try to renew the world, make himself and the others happy, and make himself deserve perfection and immortality by good thoughts, good words and good deeds. This religion is the message of truth, and a Zoroastrian perfect man is the one who thinks, acts and lives according to the truth, the one who thinks good, says good and does good.

\subsection{Manichaeism}

Manichaeism is a combination of Christianity, Zoroastrianism, Buddhism and Gnosticism which was proposed by Mani, an Iranian prophet in 300 A.D between the Chris- 
tian era and Islam. Mani was born in 215 A.D in Babylon and acclaimed to be prophet at the age of 24 . He belonged to Sabianism not Zoroastrianism, and his aim was to found a pervasive creed which could collect all people of the world under its flag and reconcile all religions and people of the world. So his religion is a composite that includes all previous instructions. He decorated his religious writings with paintings, so he was called a "painter prophet".

Mani took the concepts of "Christ the Savior" and "salvation" from Christianity and claimed that he was the prophet whose coming had been predicted by Jesus. Believing in good and evil as two forces came to his religion from Zoroastrianism, so did reincarnation and mortality principles from Buddhism. Mortification and asceticism for individual survival are the Gnostic aspects of Manichaeism.

The basic principle of Mani's thought is that the material life and all the things there have come to existence by light and darkness association, and this association has been made by an evil force not by goodness as a force. So, creation of this world is a disgusting matter. He believes that human soul is a part of god of light that has come to this world and occupied an earthly body which is dark and filthy. So, if man cares about this light in himself, he will get closer to god of light. God of light never forgets those parts of his being which suffer from filthiness, and there will be a day when he calls all those separated parts, and man and his god of light will be one. However, if he tries to set himself free from his dark body, he helps to release god of light from god of darkness sooner. To put it in simpler terms, the final goal of Manichaeism is to remove all men from the earth and return all their light aspect to god of light.

So, a perfect man in Manichaeism is a person who tries to separate light and darkness from each other. He has to set the light in his body free from materialistic evils, and this is possible only through mortification. "In Manichaeism, you can save your soul by love, faith, patience, wisdom, truth, reconciliation and joy. One should be self-contained with kindness and careless about sexual relationship. The latter is especially important because this relationship is followed by birth, and it imprisons man's soul forever. Eating too much meat is also forbidden because a creatures has a part made of light, and its body is made of a dark material. Killing an animal or cutting plants are also sins because this harms the light in animals and plants. So, followers of Manichaeism really put this world aside completely" (Bahar, 2008).

Mani, thus, taught that this world is the result of Satan or evil activities and considered it basically bad, and his goal was putting it completely aside. A perfect man in Manichaeism only pays attention to his soul which is an imprisoned light and forgets the body as well as the world and whatever in it. Hetries to set his soul free from the body prison via moral refining and avoidance of worldly pleasures to return to land of light.

\subsection{Judaism}

Judaism is one of the oldest Israeli religions with a history of more than 33 enturies. This religion is specific to Sons of Israel and is the earliest Abraham monotheist reli- 
gion. "Jews are originally Semitic. They got to worship several goddesses, proceeded to worship ghosts, then to believe in natural forces, and finally to monotheism" (Nas, 1991).

The holy book of Jews is called "the Old Testament". Christians, too, accepted this book, and the second part of it, "the New Testament", belongs to them. These two parts together is called "the Bible".

In Judaism, man has been created God-like and is superior to other creatures. This shows the man's capability of being perfect. "From the Judaist point of view, the world was spiritual and non-materialistic at the beginning of its creation, but "Adam" in the world of separation was fascinated enough to neglect his origin and disobey God. As a result of his sin, the whole spiritual world declined as to become materialistic and physical. Then the original unity of creation was abolished, and the material and spiritual worlds separated from each other" (Shaker, 2011).

In Judaism, therefore, man fell because of his original sin, and the only way after the fall was either to return to his origin or gain perfection. This perfection is possible by following wisdom and religious rules. In fact, in Judaism, "the superior goodness that all good things come from is rational perfection" (Ibid, 58).

In this religion, following wisdom and doing religious rituals are means of reaching perfection. Among all the instructions of Judaism, "the ten commandments of Moses" are the most important as follows:

1. You shall have no other gods before me.

2. You shall not make idols.

3. You shall not pronounce the name of your God for trifles.

4. Remember the Sabbath (Saturday) to keep it holy

5. Honor your mother and father.

6. You shall not murder.

7. You shall not commit adultery.

8. You shall not steal.

9. You shall not bear false witness against your neighbor.

10. You shall not be covetous (Shaley, 1976).

\subsection{Christianity}

Christianity, which appeared in the first Julian century, is according to Jesus's teachings. It is a combination of eastern Gnosticism, Jewish promised Christ, Greek thoughts, and Roman equality. This religion supports a kind of worship that puts God at the top of the society and connects man to God through Jesus, who is "the son of God". The first followers of Jesus were the Jews who performed Jewish customs and rituals perfectly. "Renan says that Christianity is the master piece of Judaism" (Durant, 1969).

The Christian holy book is in two parts, "Old Testament" and "New Testament". The former is the Jewish holy book.

Christians believe that God has created man like himself and man's ability for perfection is due to that. In Christianity, though man disobeyed God by his first sin, he can 
reveal his talents and follow salvation the discussion of the original sin is a key concept in this religion. According to a Christian belief, man was close to God and innocent at first, and he had a choice by God's will. However, he used his will against God, so he fell down from the heaven to the earth by eating the forbidden fruit to live in a world full of pains and suffering. Adam's disobedience is man's first sin that Christians generalize to the whole mankind. "They believe that, when a baby is born, apparently, it is pure and innocent, but soon afterwards evil deeds appear in him. So, in Christians' opinion, because man's nature has been mixed with sins, he cannot return to God automatically. The only solution is that God returns to man and opens his blessing and forgiving arms to him. So, it is necessary that God come in the form of a human being to create an innocent man and sacrifice himself for humanity" (Taleb Zadeh, 1995).

In Christianity, "sins came to this world by Adam's fault, and Jesus came in the form of a man to sacrifice himself willingly and undertake people's sins" (Shley, 1976). On this basis, man's perfection and salvation is possible by believing in Christ, which is different from Judaism. Also, prayers and religious rituals will not be enough for perfection, but salvation is hidden in faith and belief which can be achieved only by God's blessing. "You can move toward perfection only by God's confirmation. Perfection in Christianity means submission of heart and mind that follows faith, which needs God's blessing that makes man able to love his enemies. Love of God in Christianity is the essence of perfection" (Shaker, 2011).

As Christianity suggests, God is affectionate. "Affection and love are the basis of christianity, father of the heavens loves people like his own children, and people should love him like their father and love each other like brothers. Love of people is the main principle in Christianity. You should reconcile with enemies, get along with them, behave them as your friends and forgive them. You should be patient with evils and avoid judging people. Not doing bad deeds is not enough, nor is doing good deeds; we should imitate the heavenly father's affection and forgiveness. There are only three immortal things in the world: faith, hope and love, but the most important one is love" (Shaley, 1976).

So, from the Christian perspective, a perfect man is the one who believes in Christ completely, follows perfect sincerity and absolute submission to God, and has a pure and innocent heart. He sticks to moralities perfectly and is kind toward friends and enemies in the same way. He does not react to evil with evil, and salvation in his life comes out of his heart.

\subsection{Islam}

Islam is the last Abraham and monotheistic religion which completed all the imperfect truth and instructions that existed before it. Muslims believe that Mohammad is the last prophet and Islam is the most perfect religion. Their holy book is "Quran" which has remained unchangeable and free from any distortion since the beginning, and there is no difference of ideas among commentators about it" (Nas, 1991).

There is an extreme holiness for "man" in Islam, and human dignity is very high in 
this religion. Man's function in Islam is that he is set to do on the earth what God does in the heavens. In other words, man is the representative of God on the earth. This representation is viewed as the foremost virtue of man. His second virtue is that God created him from soil but taught him His names. There are different interpretations and comments about the nature of God's names, but there is no doubt that all represent education and teaching. Based on this knowledge, angels bowed down to man. As for the third virtue, God suggested a mission to everything including animals and plants and mountains, but they did not accept it; it was just the man who accepted it. About this mission too, there are different interpretations. So "man is God's agent, has been taught by God, is the only creature who can behave against his nature, and is responsible for his destiny because he is free to be good or bad" (Shariati, 1983).

From the point of view of Islam, man has been created innocent but his physicality leads him to evil. He can distinguish good from evil by God's inspiration and being aware of God. However, evil is in his nature; That is to say, the tendency of movement toward perfection lies in him, but making moves in this way is not easy because he has been created bi-dimensionally from God and soil. "His nature likes to stay, stop, relax and settle, but his God-granted soul likes to improve and go upward. This conflict always goes on in man till he selects one of his dimensions" (Ibid, 8).

In Islam, therefore, man is in a process of becoming, of making a choice, and of doing a campaign. He is a person who has recognized the right path, walking in this path and moving toward absolute perfection. So, man can choose this way willingly. Perfection in Islam is a balance and harmony. "With all his talents and values, man becomes perfect when he does not choose only one ability but rather pays attention to all his values. A perfect man is the one whose values grow in harmony and none of them remains undergrown. In other words, a perfect human in Islam is a balanced one" (Motahari, 1978).

Man needs a religion that can satisfy those two dimensions of his and keep him balanced. Islam takes into account all human tendencies including internal, external, individual, social, materialistic and spiritual tendencies. It supports both philosophical wisdom and logical instructions as well asgnostic love and purification of soul. "As suggested by Islam, a perfect man pays attention to both inside and outside parts and says prayers at night and works outside during the day. Islam does not reject this world and human nature, but it considers man in relation with his nature as a farmer with his farm; for a farmer, the farm is not a goal, but it is something on which to work and gain happiness. The farmer will be wrong if he chooses it as his house" (Ibid, 177).

Apparently, man in Islam is the only being whose humanity can be apart from his own self; man does not possess his individuality but he has to gain it. For gaining it, he should pay attention to his both sides, i.e. Earthly and heavenly sides. He should not pay absolute attention only to the heaven nor to his worldly desires; but rather, he should seek all his potentials, values and desires in harmony. This is what it means by a balanced man in Islam. 


\section{Conclusion}

The basis of western new thought is humanism in which man is a self-centered being who is not dependent on any greater force. Also, materialism, rationalism and denial of metaphysics form the basis of the modern western philosophy, which makes it different from eastern philosophies. In contrast to western man, the first and foremost characteristic of eastern man, owing to the influence of religions that all appeared in the east, is his faith and belief in the heaven. In eastern schools of thought, man and the world are under the centrality of God, moving toward a spiritual goal and a superior world. Among all eastern religions, Islam is the most multi-dimensional one; it takes into consideration both materialistic and spiritual dimensions of man and introduces the perfect man as the most humble creature on the earth and the most knowledgeable one in the world.

\section{References}

Aboutorabi, A. (2001). Review Criteria for Mental Health and Illness in Analytical Theory of Freud. Ma'refat Magazine, 30-50. (In Persian)

Ashoori, D., \& Chinese, E. (1963). Arash Magazine, 7, 156-167. (In Persian)

Babak, H. (1957). Main Philosophical Thoughts: Seventy Philosophical Essays (5th ed.). Gilan Press. (In Persian)

Bahar, M. (2008). Asian Religions (7th ed.). Cheshme Press. (In Persian)

Behzad, M. (1959). Darwinism: What Darwin Says (5th ed.). Nil Press. (In Persian)

Durant, W. (1969). The History of Philosophy (Translator: Zaryabkhooyi, A., 2nd ed.). Offset Company. (In Persian)

Durant, W. (1971). Pleasures of Philosophy (Translator: Zaryabkhooyi, A., 2nd ed.). Andishe Press. (In Persian)

Foroughi, M. A. (1961). Wisdom Journey in Europe (2nd ed.). Offset Company.

Mashkoor, M. J. (1980). Interfaith Great Summary of the History of Religion. Shargh Press. (In Persian)

Motahari, M. (1978). Pefect Man (4th ed.). Sadrapres. (In Persian)

Nas, J. (1991). Comprehensive History of Religions (Translator: Hekmat, A., 4th ed.). Entesharatva Amoozesh Enghelab Eslami. (In Persian)

Nietzche, F. (1956). Will to Power (Translator: Hooshyar, M.). Tehran University Press. (In Persian)

Nietzche, F. (2011). Also Sprach Zarathustra (Translator: Ansary, M.). Jami Press. (In Persian)

Palmer, M. (2009). Freud, Jung and Religion (Translator: Dehghanpoor, M., \& Mahmoodi, Gh.). Roshd Press. (In Persian)

Pirmoradi, M. J. (1995). Comparison of Islam and the Place of Man in Darwin's Theory of Evolution. Mesbah Magazine, 18-50. (In Persian)

Piyetr, A. (1973). Marx and Marxism (Translator: Zeyaee, Sh.). Tehran University Press. (In Persian)

Saneyi Darre Bidi, M. (2006). Existence in Nietzsche's Point of View. Humanities Research Magazine, 20-55. (In Persian)

Shaker, M. K. (2011). Perfectibility of Man Point of Departure in Religious Discourse. Human Religion Research Magazine, 26-53. (In Persian) 
Shaley, F. (1976). A Brief History of Religions (M. Khodayar Mohebbi Trans., 2nd ed.). TohooriLibrary Press. (In Persian)

Shariati, A. (1983). Human (2nd ed.). Elham Press. (In Persian)

Shaygan, D. (1967). Religions and Philosophical Schools of India (Volume 1). Tehran University Press.

Taleb Zadeh, H. (1995). A Look at Christianity. Ma'aref Eslami Magazine, 25-45. (In Persian)

Zarrinkoob, A. (1990). In the Realm of Conscience: A Survey of the Opinions, Religions and Myth. Elmi Press. (In Persian)

Submit or recommend next manuscript to SCIRP and we will provide best service for you:

Accepting pre-submission inquiries through Email, Facebook, LinkedIn, Twitter, etc. A wide selection of journals (inclusive of 9 subjects, more than 200 journals)

Providing 24-hour high-quality service

User-friendly online submission system

Fair and swift peer-review system

Efficient typesetting and proofreading procedure

Display of the result of downloads and visits, as well as the number of cited articles Maximum dissemination of your research work

Submit your manuscript at: http://papersubmission.scirp.org/

Or contact ojpp@scirp.org 